\title{
Bare life production and the author's criticism in the short story "Manuel" by Seno Gumira Ajidarma: the study of agamben's sociology of literature
}

\author{
Ilham Rabbani ${ }^{a,}{ }^{*}$, Aprinus Salam ${ }^{\text {b, }}$, \\ a,b Magister Sastra, Fakultas Ilmu Budaya, Universitas Gadjah Mada \\ Iilhamrabbani@mail.ugm.ac.id*; ${ }^{2}$ aprinus@ugm.ac.id \\ *korespondensi penulis
}

\begin{tabular}{ll}
\hline Article's information \\
\hline History: & : 2I Januari 202I \\
Submitted & : I April 202I \\
Revised & :30 April 202I \\
Published &
\end{tabular}

Kata kunci:

Manuel

Timor Timur

Homo Sacer

Bare Life

ABSTRACT

State of Exception

Cerpen "Manuel" karya Seno Gumira Ajidarma yang berlatar insiden Santa Cruz di Dili (I99I), mengangkat persoalan kemanusiaan dalam relasinya dengan kekuasaan negara. Warga Timor Timur kehilangan Hak Asasi Manusia (HAM) karena invasi militer Indonesia atas wilayah mereka, serta berada dalam situasi homo sacer atau bare life. Penelitian ini menggunakan teori filsafat politik yang dikembangkan oleh Giorgio Agamben. Metode yang digunakan ialah deskriptif kualitatif. Pertanyaan penelitian yang berusaha dijawab: pertama, bagaimana negara memberlakukan state of exception sehingga memunculkan bare life dalam cerpen "Manuel"?; dan kedua, bagaimana bentuk kritik pengarang lewat cerpen "Manuel" terhadap politik kewarganegaraan Orde Baru? Temuan dari penelitian ini: pertama, ditemukan motif pemberlakuan state of exception berupa dalih integrasi, antisipasi komunisme, pembangunan, serta kesepakatan terkait eksplorasi Timor Gap; dan kedua, kritik terhadap negara disampaikan lewat tuturan tokoh Manuel, peminjaman tuturan aktivis Timor Timur, dan pengangkatan wacana perlawanan terhadap militer Indonesia. Akan tetapi, strategi tersebut justru berdampak pada orisinalitas kritik yang layak dipertanyakan kembali.

Key word:

Manuel

East Timor

Homo Sacer

Bare Life

State of Exception

\begin{abstract}
The short story "Manuel” written by Seno Gumira Ajidarma set in the Santa Cruz incident in Dili (I99I), raised humanitarian issues in the relation to state power. East Timor citizens lost their human rights because of the Indonesian military invasion of their territory, and were in a homo sacer or bare life situation. This research uses the theory of political philosophy developed by Giorgio Agamben. The method used is descriptive qualitative. The research questions that are trying to be answered: first, how does the state impose the state of exception so that it raises bare life in short story "Manuel?"; and second, how does the author form of criticism through the short story "Manuel?" towards the New Order citizenship politics? The finding of this study are: first, First, the motive for the application of the state of exception is using the pretext of integration, anticipation of communism, development, and agreements related to the exploration of Timor Gap; and secondly, criticism of the state was conveyed through the speeches of the figure of Manuel, borrowing the speech of East Timor activists, and the adoption of discourse of resistance to the Indonesia military. However, this strategy has an impact on the originality of criticism which deserves to be questioned again.
\end{abstract}

Copyright (C) 2018 Universitas Ahmad Dahlan. All Right Reserved

\section{Introduction}

In the author's point of view, various phenomena in society serve as material for strategic literary work. As producers of works, authors must have more sensitivity to these phenomena. Various problems are then summarized in their works, from the problems of humans as individuals, problems of social, economic, political, to cultural in a broad sense. This is because the object of literary works is reality, whatever is meant as reality by the author (Kuntowijoyo, 2006: 17I). In this case, the reality of state life under a certain regime includes it. In Indonesia itself, more and more works discuss the complex problems during the New Order regime (1965-1998) in power, both those produced at that time and after. 
If we talk about the New Order, it is common knowledge that the regime was better known as a repressive regime under Soeharto's government than as a democratic regime. 1975 was a time when this authoritarian regime - it could even be said to be totalitarian - had its roots deep in the life of Indonesian society.

Initially, the New Order government was expected to bring about changes in the political sphere, from being previously authoritarian during the Guided Democracy under Soekarno's leadership to a more democratic government (Gaffar, 2006: 3I). However, slowly, the New Order practically fell into the same "hole" as its predecessor regime. "Maintaining national stability" was a pretext frequently used by Suharto as president to impose policies on groups criticizing his regime. Under the Pancasila Democracy government system, on the pretext of maintaining national stability, the military's role appears to be very dominant. Another characteristic of the New Order leadership was the low implementation of Human Rights (HAM) (Gaffar, 2006: I49-I50). Discipline and persecution were everywhere.

In connection with 1975, the New Order regime invaded East Timor with its military strength, which had just declared its independence (28 November 1975). Despite many controversies and international condemnation, Indonesia claimed all of East Timor as part of the Unitary State of the Republic of Indonesia (NKRI) less than a year later. In de jure, marked by the Balibo Declaration, East Timor then became the 27th province of Indonesia, which also meant that all East Timorese then had the status of Indonesian citizens (WNI). However, it seems that behind this momentum, the curbing and even cleansing of the East Timorese people have continued for years, even though they hold the status of Indonesian citizens. It is clear that the state in this situation reduces human rights in the body of every human being in general, and citizens in particular. Since then, atrocities have continued for a variety of reasons.

As already mentioned, that phenomena in society are materials for strategic work, including the incident of the East Timor occupation. Furthermore, the link between social reality and the world in literary works, according to Faruk (20I6: 5I-52): literature can be considered as a fictional and imaginative force in order to capture the social world structures that are outside and beyond the realm of direct experience, beyond. A line of objects, movements, which seem to have separated from one another.

Next, in particular, the Santa Cruz Massacre, a series of Indonesian military atrocities against the East Timor people, was brought into a literary work by an Indonesian writer, Seno Gumira Ajidarma. The incident was used as a time setting, to then set out to tell the story of the invasion in 1975. A collection of short stories entitled Mata Mata (1994) was born. Ajidarma's courage to reveal the cruelty towards the people of East Timor opened the public's eyes, and at the same time, triggered rejection of violence (Dwifatma, 20I4: xvi). Indirectly, the transfer of AJi Darma from the Jakarta Jakarta newspaper (JJ) to the Citra tabloid can also be related to the loudness of his works voicing violence. These works were inspired by and closely related to the coverage of the East Timor invasion in the newspapers $(\mathrm{JJ})$.

The object of this research is the short story "Manuel" (1992), one of the short stories in the book of Saksi Mata (the Eyewitness) short story collection (2016). The short story contains the story of the character Manuel who tells his memory of the Indonesian invasion in 1975 and the Indonesian military's atrocities against them for approximately 30 years. Regarding Ajidarma and Eyewitnesses as a whole, Fuller (20II: II) commented that Ajidarma, with his works, had indeed been a critic and opponent of the New Order regime since the 1980s.

The short story "Manuel" will be analyzed using the sociology of literature or political thoughts about the emergency developed by Giorgio Agamben. Specifically, the concepts of sovereign power, state of exception, bare life, and Homo Sacer will be highlighted. The reason was, as already mentioned, that Ajidarma's short stories in Mata Mata (spy), including the short story "Manuel," clearly reflected the human rights violations by the New Order regime against the East Timorese. It means that if we use the perspective of Agamben's sociology of literature, it can be said that there were many implementations of the state of exception enforced by the Sovereign power of the New Order so that the effect is the emergence of East Timor people who live without the shield of law, namely bare life.

In his political thinking, Agamben places the issues of democracy and human rights as central themes. It is increasingly relevant, especially when it is related to the context that the common people in Indonesia have so far devoured the term democracy as a system of government, which is something that the state would ideally like to carry out, as in the common expression, "government of the people, by the people, and for the people," which is then translated into the constitution of each country (Gaffar, 2006: 3). 
Related to democracy, Agamben has his own views. Democracy is generally imagined as a political order capable of realizing legal certainty, institutionalizing civil rights, and separating the branches of power (executive, legislative, and judiciary). Law in a democratic country always appears to carry the promise of equality, justice, and the absence of violence in life together (Sudibyo, 2019:3). However, in practice, democracies often suspend legal certainty, ignore the separation of powers, and violate civil rights when emergencies such as civil war, revolution, foreign invasion, rebellion, or the threat of terrorism occur. These emergencies have always been characterized by a suspension of law purportedly aimed at protecting people from violence. The dividing lines of legislative, executive, and judicial powers were removed, while military power was expanded to cover public affairs that were broader than just defense matters (Sudibyo, 2019: 3). Agamben called the situation as the implementation of an emergency or a state of exception.

When the state of exception is normalized, or its implementation is no longer a state of suspension of the law, but has become the law itself, then society as a whole is described as a giant prison building (camp), where violence can occur at any time (Agamben in Sudibyo, 2019: 8). This situation has resulted in a legal vacuum, where violence is inevitable. In this situation, everyone has the potential status of homo sacer: people who become objects of violence without the shield of legal protection and any consequences for the perpetrators of violence. Agamben (1998: 9) describes this homo sacer position as the subject and object of a political order when the boundaries of the separation of powers become blurred. Agamben puts the blurry image of homo sacer as the background for the logic of sovereignty; that is, if the Sovereign is above the law, homo sacer as the personification of bare life marks a domain beyond the reach of the law, but at the same time provides the basis for the existence of the Sovereign.

Furthermore, several studies that have relevance to this research are research that examines Ajidarma's works in Eyewitnesses (Saksi Mata) and research that uses Agamben's political thinking as a tool of analysis. First, Zamzuri's research (2012) reveals that the short stories in Saksi Mata describe the condition of society and the conflict in Santa Cruz. Zamzuri uses Greenblatt's New Historicism theory and concludes that the stories in Saksi Mata are part of the symbolic structure of society. In particular, the discussion of the short story "Manuel" in Zamzuri's research revolves a lot about the life journey of a character, and his stories are not seen either as a picture of the collective bitterness of the East Timorese people whose human rights were reduced or as a criticism of the New Order.

Second, Rifa'ie's research (2019). This research uses the sociological theory of literature on hegemony developed by Gramsci to explain ideological confrontation, the role of intellectual figures, and the formative role of the Saksi Mata anthology. Although referring to violence and human rights violations against the East Timorese people, Rifa'ie's research does not specify the background of the incident as this research does. The forms of criticism are also not discussed further in his research.

Third, Marhaeni and Salam's research (2020). The research examines the film Spotlight, directed by Tom McCarthy, and tries to uncover the motives for implementing a state of exception by the state, which then impacts the production and reproduction of bare life. Fourth, Pratiwi and Apriyani's research (2020). Their research focuses on the status of the Pegaten as homo sacer in the novel Kubah by Ahmad Tohari. The last two studies have relevance to this research because they both use the perspective of Agamben's political philosophy, in which there are several similarities in the aspects that are highlighted, such as state of exception, homo sacer, and bare life.

Based on the explanations above, it can be formulated that the objectives of this study are: first, to try to uncover the reasons for the application of the state of exception by the state which resulted in the production of bare life or homo sacer in the short story "Manuel"; and second, to find a form of criticism by the author through the short story "Manuel" against the New Order citizenship politics.

\section{Method}

This study employs a qualitative method. Qualitative research produces descriptive data in the form of words or writings and the behavior of the people being observed. The use of the approach is intended so that researchers are able to produce in-depth descriptions, both regarding speech, writing, and the observable behavior of certain individuals, groups, communities, or organizations in a particular context setting, as well as trying to study with a complete, comprehensive and holistic perspective Bogdan \& Taylor, I992: 2I-22). The researcher is the main instrument. The approach in this research is the mimetic approach, which sees literary works as an imitation of reality. The theory used is the sociology of literature or political thinking about the emergency developed by Giorgio 
Agamben. Specifically, the concepts regarding the sovereign power, state of exception, bare life, and homo sacer will be highlighted.

Abstracting Faruk's (2017: 22-26) opinion, the steps of this research are: first, the determination of material objects and formal objects. The material object of the research is the short story "Manuel" in Ajidarma's collection of short stories from Mata Mata (2016) published by Bentang Publisher, while the formal objects are the implementation of the state of exception, the production of bare life, and the author's criticism toward the politics of citizenship of the New Order; second, data collection was carried out by means of a literature study which functioned to find secondary texts related to research, such as texts that discussed the conflict or the Indonesian military invasion of East Timor. The technique used is note-taking; and third, the data analysis was carried out using content analysis, in which the researcher interpreted the texts classified with the Agamben political framework.

\section{Result and Discussion}

The following is a discussion on the implementation of the state of exception by the state (using the pretext of integration, anticipating communism, development, and agreements related to Timor Gap exploration) which then results in the production of bare life or homo sacer status in East Timorese people, as well as other forms of criticism from Ajidarma as the author toward the state and citizenship politics in the short story "Manuel" by Seno Gumira Ajidarma.

\section{Bare Life Production}

As already mentioned, Agamben's political views are highly relevant to the situation in Indonesia, especially if the discussion is directed at the militaristic and totalitarian context of the New Order government. The massacre incident in East Timor on the pretext of integration, development, and eradication of communism, as well as a covert agreement with Australia, is a real case. With the implementation of the state of exception, the status of homo sacer or bare life was then attached to the people of East Timor, even though they were recognized as Indonesian citizens. Human rights violations were also unavoidable. The people of East Timor were exposed to violence because of their bare life. The Santa Cruz incident becomes the short story's timeline, and then the character Manuel recounts his memories of the Indonesian invasion of East Timor in 1975 and its military atrocities for approximately 30 years.

The pretext of the imposition of a state of emergency or a state of exception is not conveyed explicitly in the short story "Manuel," but from the incident of the initial arrival of the Indonesian military to occupy East Timor, which could be related to the context or motive behind the invasion. In the short story described as follows:

"I was five years old when the raid took place. I heard explosions pounding from harbor and smoke rising from behind the roofs of the houses. ... This atmosphere I will never forget in my life because since then our peaceful life has been taken away...." (Ajidarma, 2016:2I)

"... In the sky, I saw planes spewing out paratroopers while the gunfire from the harbor was still heard. ..." (Ajidarma, 2016: 22)

As stated by Lane (2012: xiii) and Coelho (2012: 6), the political forces in East Timor after the Flower Revolution in Portugal (1975) competed for the people's votes, and Frente Revolucionaria de Timor-Leste Independente (Fretilin) became the one and the only real and legitimate force. The group that lost and left East Timor asked for the intervention of the Indonesian government, which then triggered the Balibo Declaration as an "Integral Declaration" with Indonesia. Subsequently, the MPR of the Government of Indonesia decided the 1976 MPR Decree, which de jure accepted the incorporation of the entire territory of East Timor into the Unitary Republic of Indonesia. This integration becomes the first pretext for implementing the state of exception.

Second, the pretext was the reason for the anticipation of the outbreak of communism adhered to by Fretilin in East Timor. With this pretext, Indonesia's strategy was supported by the United States in the form of weaponry assistance. It could also be suspected as the cause of human rights violations in East Timor, which was simply an agenda for the annual discussion of the United Nations (UN) without any real action. As understood, America, which adopts a capitalist economic system, and several other superpowers, dominate the decisions of the UN session. It is in line with the statement of Coelho (2012: 5) as an East Timor independence activist, that the anticommunist New Order regime, supported by a superpower, carried out political maneuvers and propaganda about communism. Fretilin did not explicitly define itself as a communist or attempt to move towards the formation of 
a communist society, but then the way people thought and viewed was influenced by the propaganda carried out by the capitalist media (Coelho, 2012: 23-24).

Third, the Government of Indonesia informs the international community that the integration mission is strengthened for development reasons, both in general development (physical areas) and development of Human Resources (HR). Based on the notes of Coelho (2012: 5I), although the Portuguese and the UN did not recognize integration, the Indonesian government in East Timor continued with all its political and legal policies, and development was mobilized based on the constitutional law of Indonesia.

Fourth, the implementation of the state of exception is also due to an agreement between Australia and Indonesia. In 1989, Indonesia held de jure recognition of integration from Australia, following the signing of an agreement between the two parties regarding cooperation in the exploration of the Timor Gap - this agreement was more of a political instrument, rather than an economic wealth sharing contract 2012: 57-58).

The East Timor problem then escalated to the conception of human rights, which should protect humanity indiscriminately. However, in the conception of the Universal Declaration of Human Rights formulated by the UN General Assembly, the concept of human rights is only attached to the concept of a nation-state. It means that there is no law in their bodies when the state throws away its citizens. They even have their status as human beings without human rights at all. According to Coelho (2012: 43-44), human rights violations in East Timor were indeed condemned by the United Nations, but without concrete actions to implement their resolutions. As a result, violence continued against the people of East Timor.

The time setting used by Ajidarma in the short story "Manuel" is the year of the Santa Cruz incident (I99I), but it tells of the invasion since the beginning (I975) through the narrative of the character Manuel who is being spied on by intelligence (the narrator, as well as the "me" character). Manuel also spoke about the continued resistance of the Forcas Armadas De Libertacao Nacional De Timor Leste (Falintil) soldiers who were based in the forest, which was the armed wing of Fretilin. This setting can be identified by Manuel's age in the quote:

"I was five years old when the raid took place. ...." (Ajidarma, 2016:2I)

"I lived in the forest until I was I7. During that time, I have witnessed how life goes on in the shadow of death. ...” (Ajidarma, 2016: 25)

"'How old are you, Manuel?"

'Almost 2I. Why?'

I thought he was 30. Does suffering make a person grow old?” (Ajidarma, 2016:27)

In the short story "Manuel," Ajidarma only provides a kind of time marker (at the age of 5) as a form of information when the invasion took place. The motive for the implementation of the state of exception is not explicit in the short story so that supporting data is needed from secondary texts, references related to the Indonesian invasion of the East Timor region. Some of the arguments that have been mentioned above are arguments that the researcher encountered in secondary texts, and in fact, they are implied through the time marker in the short story "Manuel" as a literary text.

Next, with the implementation of the state of exception by the regime, the status of bare life was automatically attached to the people of East Timor at that time. In the short story, the cruelty of treatment or human rights violations against them is described as bombing and shooting from the port, which is marked by various explosions and panic situations of the residents in saving themselves (p. 2I),

"I heard explosions pounding from the harbor and smoke rising from behind the roofs of the houses. I saw people running here and there in front of the house in a panic. "The warships are shooting," I heard a man screaming as he ran." (Ajidarma, 2016:2I);

the invasion resulted in large-scale fleeing of people to the forest (p. 22),

"Mother grabbed my hand and walked hurriedly to follow the other people, who were walking in more and more droves in one direction. Then, I will find out, we all fled.” (Ajidarma, 2016: 22);

destruction rocket fire at night aimed at the East Timorese, which immediately destroyed their joy ( $p$. 22), 
"I remembered the dimly reddish twilight sky as if drowning our previously carefree lives into the dense darkness of the night that was occasionally lit by the light of rockets fired to destroy us." (Ajidarma, 2016: 22);

indiscriminately torture, including the elderly, women, and children, or anyone deemed suspicious by the Indonesian military (pp. 23 and 26-27),

"The next day I was told that my mother was shot and died instantly at that time. My baby brother was crawling among the people who ran here and there." (Ajidarma, 2016:23)

"Yelling, threats, and punches were not enough. My grandmother, you know, my grandmother, who was 74 years old, had her cheek skin sliced off and told to eat it raw to be asked what it tasted like." (Ajidarma, 20I6: 26-27);

the scattered corpses, the pools of blood, and the bones of people slain (pp. 24 and 25),

"I saw corpses lying along the road, and I ran over the dead bodies, as well as the dying people, crying. Sometimes, I slipped by a pool of blood." (Ajidarma, 2016:24)

"All the way home, we waded through the sea of scattered bones. Every now and then, a skull rolled past from nowhere. We knew, these are the unburied bones of our brothers." (Ajidarma, 2016: 25);

the long bombing, for three months, which resulted in the horror beyond the limits experienced by Manuel and other East Timor people (p. 24),

"It turned out that the bombing lasted for three months. Our fears and horror have completely disappeared because perhaps we have reached its peak." (Ajidarma, 2016:24);

and the significant impact of the Indonesian invasion of East Timor is the drastic reduction of the East Timor population (p. 25),

"I lived in the forest until I was I7. During that time, I have witnessed how life went on in the shadow of death. Marriage among partners, births, and burials all took place with the feeling that there will be a deadly attack every moment. Our numbers have dwindled.” (Ajidarma, 2016:25).

These atrocities are in line with the description of Rei (2017: I) in his memoir, that the Indonesian military landed by parachute, pointed bullets at the East Timorese people, and immediately spread like a virus in various directions. Apart from that, the Santa Cruz incident was no less terrible. Rei (2017: 55-56) describes the threat made by the military when the people protested and sometimes attacked the Montael Church complex to hunt down youths who were in hiding. Sebastiao was the victim who was shot.

If it is seen up close, some of the excuses used by the Indonesian government to impose a state of exception tend to appear as favorable policies. However, in practice, there were violent massacres. The short story "Manuel" clearly represents this. The communist-leaning Fretilin motive may indeed imply a strategy of violence in the integration process, but the question then arises: why were the killings and torture committed against all East Timorese?

It indicated that the enforcement of the state of exception should only have an effect on the production of bare life in Falintil soldiers in particular, or even Fretilin activists in general, and not all East Timorese. Atrocities committed by the military continued for decades until the intervention of the United Nations and the 1998 Reformation in Indonesia. Reformation changed politics and government policies, both at home and abroad.

It means that the state of emergency or state of exception was normalized for East Timor by the New Order government, which claimed the area as its 27 th province, whereas in a democratic regime, the state of exception should have been abnormal. The normalization of the state of exception was marked by constant interrogation and torture of citizens suspected of having contact with Fretilin and the spread of intelligence in almost all areas suspected of being the base for supporters of Fretilin or the Falintil movement. It can be said as a representation of Agamben's words that the totalitarian regime "secretly infiltrated" in the body of democracy, or democracy is a continuation of totalitarianism: both are not discontinuity continuity, even intensification of camp logic. All 
decisions, including the imposition of a state of emergency, were in Suharto's hands so that the principle of separation of powers in Indonesian democracy was blurred and unclear.

\section{Author's Criticism}

In understanding Ajidarma's criticism as the author of the New Order citizenship politics, Goldmann's view can be used (in Faruk, 2016:6I), which states that literary work is basically a structuring activity motivated by the desire of the literary subject (in this case the author) to build a balance in the relationship between himself and the surrounding environment. It means that Ajidarma's criticism through the short story "Manuel" against the New Order regime, which incidentally influenced policies that had an impact on his life as part of society, was an effort to build a balance between himself and his surroundings.

Manuel's words in the short story can represent Ajidarma's thoughts or even his criticism of the state (New Order). It can be understood, as an author defending the East Timorese, that Ajidarma's status in the New Order order could be said to be homo sacer, because his writings were deemed to be disturbing the stability of the regime. Apart from the character's words, his confession in Ketika Juralisme Dibungkam Sastra Harus Bicara (When Journalism is Silenced, Literature Must Talk) also strengthens that the short story "Manuel" is a representation of his criticism, but by borrowing facts according to what activists say. Ajidarma explained that he met and chatted with several East Timorese activists about the history of the formation of their province, as well as the bitter experiences he had experienced. Ajidarma then wrote each of their stories into the work after the conversation was over, and the contents reflected the facts based on the stories of the activists (Ajidarma, 1997: 85). Finally, in the short story "Manuel," the discourse on East Timor's resistance to the Indonesian military is always alluded to after the disclosure of atrocities against the people.

Ajidarma's style in delivering criticism in his short stories is often satirical, although there are also some straightforward criticisms. The forms of Ajidarma's criticism as the author toward the New Order citizenship politics are as follows.

First, Ajidarma criticized the Indonesian government's policies as if they were always right, including in the context of their invasion of East Timor. This criticism can be seen in the quote from the conversation between Manuel and the intelligence figure as the narrator (p. 23):

"I lit a cigarette, but immediately I turned it off. According to the government, smoking is harmful to health. Isn't the government always right? As soon as Manuel arrived, he lit a cigarette. I warned him.

"According to the government, smoking is harmful to health."

Manuel smiled.

"Indeed, your government is always right," he said." (Ajidarma, 2016:23)

Second, using a stinging satire, the author also touched on the suffering of Manuel and the East Timorese people, who seemed to transcend film scenes due to the atrocities that had befallen them. This criticism is also seen in the conversation between the character Manuel and the narrator (p. 24):

"I interrupted.

"How come? it's like a movie."

"Life is just like a movie, man."

I looked at Manuel, not like a boaster." (Ajidarma, 2016:24)

Third, the depiction of children seeing cannon fire as fireworks at night can be interpreted as a criticism of the very tragic circumstances experienced by the East Timorese due to the Indonesian invasion. In East Timor, children enjoyed deadly cannon fire as little more than entertainment (p. 24):

"We went to the top of the hill at night, waiting for cannon fire from the ship like waiting for a fireworks display." (Ajidarma, 2016: 24)

Fourth, almost similar to the second criticism, the author mentions the life experienced by the East Timorese. Because of the invasion, they indulged in a more intoxicating life than beer. This criticism is contained in the quote: (p. 26):

"The beer in the pitcher ran out. The world seemed to be floating. Manuel ordered another pitcher. 
'Beware, you'll get drunk.'

'It won't be as drunk as my life, my friend." (Ajidarma, 2016: 26)

Fifth, the author's criticism is also conveyed by describing the ambivalence of the intelligence who is too quickly sick to hear stories of atrocities, even though in the field, they are involved in torture and massacres (p. 27):

"My grandmother, you know, my grandmother, who was 74 years old, had her cheek skin sliced off and told to eat it raw to be asked what it tasted like.

I quickly felt sick.

'So, what was your grandmother's answer?'

"Like human flesh."

I went to the toilet. Damn! He brought out all the sirloin steak I ate earlier. What a jerk!" (Ajidarma, 2016: 27)

If the five previous criticisms were delivered in the form of satire, then there was also criticism from Ajidarma as the author, which was delivered in a frank and straightforward message, for example, regarding the issue of the resistance of the East Timorese people that would not stop (p. 25),

"Our brothers who did armed fight in the mountains advised us to surrender not to fall further. He said that we must not become extinct to continue the struggle." (Ajidarma, 2016:25)

and the stand and aspirations of the people who are always oppressed through arrest, imprisonment without trial, and cruel torture in them (p. 26).

"We go to school, but we should not think in our way. We do not speak our language, we do not study our history, and we cannot possibly express our stand and ideals because every time we do that, there will always be someone arrested, tortured, and jailed without trial." (Ajidarma, 2016:26)

However, what is noted from Ajidarma's criticism: first, the "borrowing" of facts according to the statements of East Timor activists as a way of criticism seems to have an impact on the originality of the criticism raised by the author himself, where his personal views or criticisms of the regime that imposed state of exception became as if not loud enough. Second, the notes for his criticism are added by his admission regarding the video leakage of the Santa Cruz incident, when he was still the Chief Editor of Jakarta Jakarta, that he is still trying to take a position not against the government. The statement is as follows.

"... So, the issue came out, in which the results of the video recordings were rewritten in detail, but we call the video itself a provocation tool. The disclosure of the recording contents is our duty to convey information, such as what was recorded by the camera, while the term provocation is used to describe JJ's position, which is not against the government. We also did a similar thing in reporting students' demonstration from East Timor in front of Hotel Indonesia....” (Ajidarma, 1997: 5I)

As if there is ambivalence in Ajidarma as the author, his stance in "Ketika Jurnalisme Dibungkam Sastra Berbicara" deserves to be questioned. Presumption regarding his indifference for being a defender or voice of the people of East Timor who experienced a reduction in human rights may arise. Thus, his credo about "literature that speaks with the truth" and the attempt to "cover-up facts is a political act, covering up the truth is the most stupid thing that humans can do on earth," could be "lying" and "paralyzed" in his own hands.

\section{Conclusion}

Based on the analysis of the short story "Manuel" by Ajidarma, the following conclusions can be drawn. First, the motives for the application of the state of exception by the sovereign power (New Order) were found, namely the use of excuses in the form of the problem of integrating East Timor into the territory of the Republic of Indonesia; the anticipation of the outbreak of communism adhered to by Fretilin; development reasons, both 
general (physical) development, and human resource development; and as a result of an agreement between Australia and Indonesia regarding cooperation in the exploration of the Timor Gap. With the implementation of the state of exception, the bare life status was automatically attached to the people of East Timor at that time. The excuses used by the sovereign power to enforce the state of exception tend to appear as favorable policies. However, in practice, the production of bare life necessitated violence in the form of the massacre of the East Timorese people.

Second, regarding the author's criticism about the state, Manuel's words can manifest Ajidarma's thoughts or even his criticism of the New Order. He also borrowed facts according to the words of East Timor activists as the "voice" of his criticism. Besides, the discourse of East Timor's resistance to the Indonesian military was always touched upon after the disclosure of atrocities against the people. Ajidarma's delivery style in the short story "Manuel" is often satirical, although there are also direct and straightforward criticisms. However, it should be noted that the critical strategy he uses, especially the "borrowing" of words from East Timorese activists, has an impact on the lack of criticism from the author himself, especially when it is related to his confession in the book Ketika Jurnalisme Dibungkam Sastra Harus Bicara, the originality of the criticism is questionable.

\section{Acknowledgement}

The author would like to thank those who have played a role in helping this research, including the lecturer as the supervisor in the research preparation process and fellow lecturers who spent much time discussing with the author. Furthermore, thanks are also given to the editorial team of the Bahastra Journal, who has assisted in the publication of this article.

\section{References}

Agamben, Giorgio. 1998. Homo Sacer: Sovereign Power and Bare Life. Stanford, CA: Stanford University Press. Ajidarma, Seno Gumira. 1997. Ketika Jurnalisme Dibungkam Sastra Harus Bicara. Yogyakarta: Yayasan Bentang Budaya. Ajidarma, Seno Gumira. 2016. Saksi Mata. Yogyakarta: Bentang Pustaka.

Bogdan, Robert, and Taylor. 1992. Pengantar Metode Penelitian Kualitatif. Surabaya: Usaha Nasional.

Coelho, Avelino M. 20I2. Dua Kali Merdeka: Esei Sejarah Politik Timor Leste. Yogyakarta: Penerbit Djaman Baroe.

Dwifatma, Andina. 2014. "Kerja Pengarang Dan Jejak Cerita SGA.” in Senja dan Cinta yang Berdarah. Jakarta: Kompas.

Faruk. 2016. Pengantar Sosiologi Sastra: Dari Strukturalisme Genetik Sampai Post-Modernisme. Yogyakarta: Pustaka Pelajar.

Faruk. 2017. Metode Penelitian Sastra: Sebuah Penjelajahan Awal. Yogyakarta: Pustaka Pelajar.

Fuller, Andy. 20I I. Sastra Dan Politik: Membaca Karya-Karya Seno Gumira Ajidarma. Yogyakarta: INSIST Press.

Gaffar, Afan. 2006. Politik Indonesia: Transisi Menuju Demokrasi. Yogyakarta: Pustaka Pelajar.

Kuntowijoyo. 2006. Budaya Dan Masyarakat. Yogyakarta: Tiara Wacana.

Lane, Max. 2012. “'Kata Pengantar.” Pp. ix-xvii in Dua Kali Merdeka: Esei Sejarah Politik Timor Leste. Yogyakarta: Penerbit Djaman Baroe.

Marhaeni, Innezdhe Ayang, and Aprinus Salam. 2020. "Pelaku Kekerasan Seksual Dalam Lindungan Negara: Film 'Spotlight' (20I5) Arahan Tom McCarthy Berdasarkan Filsafat Politik Giorgio Agamben.” Sintesis I4(I):59-77.

Pratiwi, Wista Ayu, and Tristanti Apriyani. 2020. "Homo Sacer Orang Pegaten Dalam Novel Kubah Karya Ahmad Tohari (Perspektif Giorgio Agamben).” Mimesis I(2):66-76.

Rei, Naldo. 2017. Timor Timur: Sebuah Memoar. Yogyakarta: Penerbit Circa.

Rifa'ie, Muhammad. 2019. "Konfrontasi Ideologi, Peranan Tokoh Intelektual, Dan Peranan Formatif Antologi Saksi Mata Karya Seno Gumira Ajidarma (Ideological Confrontation, The Role of Intellectual Characters, and Formative Roles of Anthology Saksi Mata Written by Seno Gumira Ajidarma).” Kandai. doi: 10.26499/jk.vI5i2.I647.

Sudibyo, Agus. 2019. Demokrasi Dan Kedaruratan: Memahami Filsafat Politik Giorgio Agamben. Tangerang Selatan: Marjin Kiri.

Zamzuri, Ahmad. 2012. "Refleksi Kultural Dalam Kumpulan Cerpen Saksi Mata Karya Seno Gumira Ajidarma.” Pp. 25I65 in Seminar (Diskusi) Ilmiah Kelompok Peneliti Kebahasaan dan Kesastraan di Lingkungan Badan Pengembangan dan Pembinaan Bahasa Kementerian Pendidikan dan Kebudayaan. Yogyakarta: Balai Bahasa Daerah Istimewa Yogyakarta. 